\title{
O 5 DE OUTUBRO NA ESCRITA DIPLOMÁTICA LUSO-BRASILEIRA
}

\author{
OCTOBER 5 IN LUSO-BRAZILIAN DIPLOMATIC WRITING
}

Caio Boschi*

\section{RESUMO}

Este texto tem como objetivo narrar os acontecimentos respeitantes à Proclamação da República Portuguesa, ocorrida em 5 de outubro de 1910, e outros que lhes são imediatamente correlatos. Embora conhecidos, os fatos aqui expostos baseiamse em documentação, na maioria, inédita. A abordagem realiza-se de forma essencialmente descritiva, utilizando-se de fontes textuais, constituidas por ofícios, relatórios e, sobretudo, telegramas expedidos e recebidos pelos serviços diplomáticos de Portugal e do Brasil.

PALAVRAS-CHAVE: República Portuguesa. Diplomacia. Fontes históricas. Correspondências.

\begin{abstract}
This text aims to narrate the events concerning the proclamation of the Portuguese Republic, which took place on October 5, 1910, and others that are immediately related to them. Although known, the facts presented here are based on mostly unpublished documentation. The approach is essentially descriptive, using textual sources, consisting of official letters, reports and, above all, telegrams sent and received by the diplomatic services of Portugal and Brazil.
\end{abstract}

KEYWORDS: Portuguese Republic. Diplomacy. Historical sources. Correspondence.

\section{ALGUNS ANTECEDENTES}

Em 1908, por iniciativa do governo da República dos Estados Unidos do Brasil, organizaramse, principalmente no Rio de Janeiro, comemorações alusivas ao centenário da abertura dos portos brasileiros ao comércio das nações. No âmbito dos eventos, foi projetada - e levada a efeito - uma grande exposição nacional, nela estimulando a participação da monarquia portuguesa. O rei D. Carlos e a rainha D. Amélia eram convidados especiais, desiderato frustrado pelo regicídio de $1^{\circ}$ de fevereiro.

\footnotetext{
* Professor aposentado do Departamento de História da Universidade Federal de Minas Gerais (UFMG) e Professor Titular da Pontifícia Universidade Católica de Minas Gerais (PUC Minas). Doutor em História Social pela Universidade de São Paulo (USP).E-mail: caioboschi@hotmail.com
} 
$\mathrm{Na}$ concepção dos promotores, a distinção tinha o caráter simbólico de configurar o estreitamento dos laços entre os dois países, fruto, em particular, do empenho do conselheiro João de Oliveira de Sá Camelo Lampreia, chefe da representação portuguesa no Brasil. A esses esforços e com idêntica ênfase somavam-se ações gestadas pela Sociedade de Geografia de Lisboa, acima de tudo pelo seu presidente Zófimo Consiglieri Pedroso que, no entanto, veio a falecer em setembro de 1910. Com a sua morte, houve o arrefecimento do intento.

Fosse como fosse, em 1910, apesar de evidente inexistência de um plano norteador da política externa portuguesa, eram intensas e densas as relações comerciais luso-brasileiras e expressiva e constante a deslocação de portugueses rumo à nação sul-americana. Naquele ano, o movimento de navios entre o porto de Lisboa e o do Rio de Janeiro, "com insignificante diferença", foi o mesmo do anterior, representado por 252 navios entrados e por 406 saídos, segundo relato de Artur Teixeira de Macedo, então cônsul do Brasil na capital portuguesa. "Como de costume todos os anos, ainda que pouco sensivelmente", aumentara a exportação de produtos portugueses para o Brasil e, inversamente, houve decréscimo na exportação de produtos brasileiros para Portugal. Calculava o diplomata que, na altura, 1.200.000 portugueses eram residentes no Brasil, com fluxo anual situado entre 30 e 40.000 emigrantes, "na maioria jovens com idade aproximada de 17 anos" (7). ${ }^{1}$

Na edição de 20 de março de 1910, o Diário de Notícias, periódico lisboeta, publicou o relatório sobre a imigração para o Brasil que João Joaquim Salgado, visconde de Salgado e cônsul geral de Portugal no Rio de Janeiro, encaminhara ao Ministério dos Negócios Estrangeiros. No documento, destacava o primado de Portugal nos contingentes de imigrantes arribados em portos brasileiros, especialmente nos do Rio de Janeiro e no de Santos, denotando que "a qualidade da imigração tem melhorado muito", sobretudo pela "miragem dourada que os portugueses mantém no espírito a respeito das riquezas lendárias do Brasil, riquezas fáceis de colher que tanto absorvem as imaginações dos nossos descuidadosos patrícios em fantásticos sonhos e que para tantos se têm transformado em tão cruéis desenganos."

À significativa ressalva, o cônsul Salgado aduzia informações sobre imigrantes procedentes de outros países europeus afirmando, com desalento, que os portugueses já não preponderavam "nem no comércio, nem em manifestação alguma da cultura humana", uma vez que "povos mais cultos, com a sua imigração pouco numerosa, mas composta de indivíduos mais preparados, têm-nos tomado o nosso antigo lugar, expulsando lentamente a nossa antiga influência: no sul até São Paulo, os alemães; em São Paulo e Minas, os italianos; da Bahia até o norte, os galegos;"

\footnotetext{
1 Tendo em vista a natureza do texto, as limitações gráficas estabelecidas e, principalmente, a profusão de fontes documentais utilizadas buscou-se abrandar a aridez informativa com a opção de referenciar os documentos textuais expostos no corpo do texto pela numeração atribuída ao conjunto documental a que cada peça pertence no acervo das duas instituições de pesquisa consultadas. Por conseguinte, os números inseridos entre parêntese, quase sempre no final de frases ou parágrafos, remetem à unidade de instalação dos documentos. Esclareça-se também que, infelizmente, eles não têm cotação/referenciação própria, encontrando-se armazenados de forma "avulsa", isto é, individualizada, não encadernada nos fundos, séries, maços ou pastas nas quais estão custodiados. Quando, no entanto, é efetuada a transcrição de trecho ou de registro de livro, a numeração fazse acompanhar da folha ou página pertinente.
} 
É nesse contexto que, visando impulsionar as relações bilaterais, por ofício de 3 de outubro, Salgado encaminhou ao diretor geral do Ministério das Relações Exteriores do Brasil cópia de decreto de 6 de setembro de 1910 do governo português que, "por uma deferência especial com a nação brasileira", concedia equiparação aos cursos de instrução secundária desenvolvidos no Brasil, validandoos para matrícula nas escolas de ensino superior de Portugal, "sem dependência das formalidades exigidas com respeito aos próprios institutos secundários portugueses" (8).

Demais, em tempo de substituição de pequenos e lentos vapores por grandes e velozes embarcações, em fins de setembro de 1910, incrementavam-se os contatos entre os dois países com o estabelecimento, pela Companhia Lloyd Brasileiro, de carreira marítima unindo o Rio de Janeiro a Lisboa (2), cuja viagem inaugural teve suas festividades noticiadas pelo conde de Selir, delegatário de Sua Majestade Fidelíssima no Brasil, na qualidade de enviado extraordinário e ministro plenipotenciário em missão ordinária (12).

\section{O 5 DE OUTUBRO}

Em 4 de outubro, por telegrama da lavra de José Pereira da Costa Mota, enviado extraordinário e ministro plenipotenciário em missão ordinária da Legação do Brasil em Lisboa, o Ministério das Relações Exteriores, na pessoa de seu titular, o barão do Rio Branco, recebeu a seguinte mensagem:

\footnotetext{
Rebentou esta noite uma revolução. Alguns regimentos se passaram para os revolucionários. Cruzador São Rafael insubordinou-se. Houve batalha nas ruas durante toda [a] noite. Agora, nove horas [da] manhã, ouve-se fuzilaria [em] diversos pontos [da] cidade. Situação gravíssima. Marechal [Hermes da Fonseca, do exército brasileiro] está ainda [no] Palácio [de] Belém (5).
}

No dia seguinte, novo telegrama informava que a "revolução" (sic) era triunfante em Lisboa; que a Armada, na sua totalidade, se insurgira; que diversos regimentos de artilharia e de infantaria tinham aderido aos revoltosos; que havia tranquilidade na cidade, que a bandeira revolucionária já se mostrava hasteada nos edifícios públicos, desconhecendo-se o destino do rei D. Manuel II e sabendo-se da constituição do novo regime sob a presidência de Joaquim Teófilo Braga (5).

No dia 6, outra mensagem cifrada relatava ao barão do Rio Branco que o governo provisório comunicara formalmente às missões diplomáticas acreditadas em Lisboa a proclamação da República, que estaria aceita e assegurada em todo o país. Salientava que, malgrado circularem "em toda parte populares, marinheiros [e] soldados revoltosos armados, não tem havido saques e nem ataques às pessoas." Outrossim, considerava o diplomata brasileiro que a "população tem tido comportamento correto" e que soubera do embarque da família real portuguesa na praia de Ericeira, "ignorando-se o destino." (5).

Descrição mais pormenorizada, misto de depoimento e de avaliação dos fatos, foi produzida passados dez dias do eclodir do movimento. Nela, Costa Mota começou por dizer que, "não obstante estar com o ânimo [...] da gravidade da situação, [...] não acreditava que tão proximamente arrebentasse 
a revolução." Admirava-se que a revolta não tivesse sido sufocada, pois "o ministério tinha sido avisado" de que, na noite de 3 de outubro, "haveria uma tentativa, da parte dos republicanos, "para apoderaremse do rei [D. Manuel II], quando ele saísse do Paço de Belém, após o jantar com o marechal [Hermes]." Além disso, autoridades civis e militares contatadas pelo diplomata brasileiro nos dias anteriores desdenhavam as notícias prenunciadoras do movimento. Julgavam que, na hipótese de ele eclodir, "seria sufocado facilmente." Sem desconsiderar que, a seu juízo, as autoridades ignoravam que as tropas supostamente leais à monarquia, em verdade, tinham sido cooptadas pelos republicanos ou que a estes adeririam sem titubeações. Categórico, interpretava: "a Revolução não malogrou devido às forças do mar." Os rebeldes de terra "foram muito auxiliados pelas forças de mar", como atestam os motins e o aprisionamento de oficiais de três importantes navios de guerra e, em seguida, os disparos destes provenientes em direção ao Palácio das Necessidades, onde se encontrava D. Manuel II. Quanto à conflitualidade, conjecturava: "[...] dizem que a maior parte dos tiros, de um lado e de outro lado das tropas que se batiam, era para o ar, porque os soldados não queriam visar-se mutuamente.” Menos evasivo, fazia saber: "os republicanos da propaganda dizem hoje que a República lhes foi dada ou entregue e não obtida pela força das armas. Isso dará ideia a Vossa Excelência do estado de imoralidade e desorganização a que deixaram chegar este país os partidos políticos que o governaram.” À guisa de conclusão, notificava: “[...] chegam notícias de toda parte do país assegurando que reina a maior tranquilidade e que tudo se está passando como se não se tivera dado uma mudança no regime de governo em Portugal [...] visto haver sossego e paz; a julgar pelas notícias transmitidas de todos os cantos, brevemente serão satisfeitos os ardentes desejos do governo provisório" (2).

Zeloso em suas diligências, o ministro brasileiro parecia estar em condições de realizar apreciação substanciosa dos acontecimentos, pois, além de investido naquela função havia cerca de um ano e meio, conhecia Lisboa e seus meandros políticos e cultivava círculo de boas amizades, porquanto já servira naquele posto diplomático (1).

\section{O MARECHAL EM MEIO À PROCLAMAÇÃO}

Vencedor nas eleições havidas em março de 1910, proclamado presidente da república pelo congresso brasileiro em fins de julho, antes de ser investido no cargo o marechal Hermes da Fonseca empreendeu viagem de cunho particular à Europa. Assim, no início de outubro, chegou a Lisboa, onde estivera, de passagem para Berlim, em 1908, e, mais recentemente, em maio do corrente ano (1).

Acolhido com entusiasmo pelas autoridades monárquicas na condição de convidado de D. Manuel II, hospedou-se, como referido, no Palácio de Belém, onde, durante jantar por ele oferecido a Sua Majestade Fidelíssima, a insurreição republicana foi-lhes anunciada.

Dadas as contingências, na tarde de 4 de outubro Hermes da Fonseca reembarcou no encouraçado São Paulo, lá permanecendo por dois dias, antes de iniciar viagem de regresso ao Brasil. Nesse ínterim, "não mais saiu a bordo", tendo ali recebido um emissário que lhe apresentou a relação 
dos integrantes do novo governo, comunicação sobre a qual, agradecido, Hermes não se manifestou, ponderando que ela fosse encaminhada à representação diplomática brasileira em Lisboa. (5).

Pouco antes de retornar ao seu país, o marechal foi visitado pelo presidente do governo provisório, seu amigo e escritor Teófilo Braga, juntamente com os ministros da Justiça, Afonso Costa, e do Interior, Antônio José de Almeida. Protocolarmente, assinalou-se que o encontro se dera em caráter particular (5).

Concomitantemente, a Legação do Brasil, por veemente determinação do ministro Rio Branco, se ocupava em desmentir que Hermes da Fonseca, no 5 de outubro, passeara de carro pela capital portuguesa a convite e em companhia do presidente Teófilo Braga, conforme noticiário amplamente divulgado em Paris e em Londres (5).

Por fim, telegrama de 7 de outubro expedido por Costa Mota e dirigido a Rio Branco dava conta que o presidente eleito partira no dia anterior, quando "tudo começa [a] entrar [na] normalidade, com o comércio lisboeta tendo suas portas abertas, as repartições públicas funcionando, as notícias do interior do país afirmando 'haver tranquilidade, estando proclamada a República por toda parte'.” E, encerrava o diplomata brasileiro: “julgo [a proclamação da] República fato consumado e peço a Vossa Excelência instruções para entrar em relações oficiais com [o] governo [provisório]" (5).

Sobre o contexto, no dia 11, Costa Mota voltava a dar ciência a Rio Branco: “[...] de ontem para hoje não se deu um só tiro na cidade e, a julgar pela tranquilidade que se diz reinar em todo o país, é de presumir que nenhum ato do lado monárquico tenha perturbado [...]a paz.” Opinante e agudo, sem meias palavras, revelava o seu sentimento de "revolta pelo procedimento dos que se diziam monárquicos não somente porque abandonam el-rei em momentos tão angustiosos, como por estarem quase todos passando para a República sem ao menos terem o decoro de esperar algum tempo para o fazerem" (2 e 5).

\section{DESDOBRAMENTOS}

Entretanto, em 8 de outubro, Costa Mota informou ao barão ministro que cessara a luta em Lisboa, após tiroteio havido entre o "colégio jesuíta e povo e força militar" e que "muitíssimos" empregados públicos e oficiais do exército tinham aderido à República, a qual, segundo avaliava, parecia "estar aceita em todo o país". Ainda no telegrama, dizia ter acabado de encontrar-se com o ministro dos Negócios Estrangeiros, a quem comunicara a autorização do presidente da república brasileira para manter relações com o governo provisório, informando-lhe, ainda, que o reconhecimento seria efetuado tão logo o novel regime tivesse "o apoio do povo e fosse aceita por todos ou quase todos a nova forma de governo", ao que aquela autoridade reagira comovidamente, agradecendo "com efusão" e afirmando ser o representante brasileiro "o primeiro em missão que encetou relações com o governo provisório" (5). 
No mesmo dia, mediante outro telegrama, Rio Branco inquiria sobre o nome oficial: "se República de Portugal ou República Portuguesa" e reiterava a prescrição , determinando que o diplomata brasileiro "procure conhecer [as] instruções [de] seus colegas [norte-]americano, francês [e] argentino", sem dar-lhes "particularidades" daquelas que recebera. Prosseguia instando-o a dizer ao ministro dos Negócios Estrangeiros e ao presidente que, tendo o conde de Selir solicitado irrevogável demissão da Legação no Rio de Janeiro, convinha "não demorar [na] nomeação [de seu] sucessor, ainda que provisória." Finalizando, apontava para uma questão a que recorreria: a falta de notícias diretas de adesão ao novo regime político por parte das províncias, visto que os informes procediam sempre de Lisboa, o que lhe soava suspeito. Com a agravante de "boatos de resistência" circularem no estrangeiro, indicando que a "revolução [estava unicamente] localizada em Lisboa (6).

No dia imediato, em resposta, Costa Mota, após informar o nome oficial do regime político recém instalado, dava a conhecer seus entendimentos com os colegas e as conversações levadas a termo junto às autoridades objetivando o rápido preenchimento do posto diplomático no Rio de Janeiro, tal como asseverava ser "crença geral que a totalidade, se não a maior parte do país aderiu à República, tendo havido luta somente em Lisboa." Complementava o relato referindo-se à aprovação de decreto de anistia por crimes de imprensa e à expulsão de padres jesuítas e de religiosas, diante da disposição governamental de aplicar integralmente a legislação sobre as associações religiosas (5).

Do Rio de Janeiro chegavam a Lisboa informações controversas, a exigir comprovação de veracidade. No dia 9: "telegramas dão notícias que suponho inexatas. Primeira: terem sido assassinados vários padres, frades [e] freiras. Segunda: duzentas freiras presas no Arsenal, entre elas várias grávidas, outras com crianças de meses [...]. Diga o que sabe sobre esses pontos" (6). A 11 de outubro: "jornais franceses [e] ingleses falam das violências aí praticadas contra conventos e contra freiras [e] frades. [...]. Excesso [de] anticlericalismo está produzindo má impressão mesmo em países protestantes” (6).

Dois dias depois, as apreensões adquiriam mais forte tonalidade. O ministro Rio Branco apresentou a Costa Mota novos informes e orientou-o quanto às providências a serem logo cumpridas. "Um telegrama diz, ontem, [que] embarcaram aí para o Brasil muitos frades e freiras. Espero seja inexata notícia. Previna [o] Núncio que remessa de religiosos expulsos para aqui daria lugar [a] desordens [e] prejudicaria [a] situação dos religiosos que aqui se acham e provavelmente traria medidas contra os religiosos estrangeiros. Exaltados já fizeram meetings anteontem [e] apedrejaram o convento [da] Ajuda. Destacamentos [de] polícia estão guardando residência [dos] jesuítas e conventos. Vários jornais abriram campanha contra conventos. Melhor é dirigir para Estados Unidos [ou] outros países [os] religiosos expulsos. [O] chefe positivista apareceu [na] imprensa condenando excessos [e] pedindo respeito aos religiosos e à religião católica. Certo é que, nos Estados Unidos e [na] Inglaterra, eles vivem em paz. Vários jornais parisienses têm verberado [os] excessos de Lisboa" (6). 


\section{OS CONSULADOS SE MANIFESTAM}

No acervo documental da Legação de Portugal no Rio de Janeiro, na forma de telegramas, registram-se as reações dos consulados sob sua jurisdição relativamente ao 5 de Outubro. Nesse dia, o cônsul na Bahia buscava elucidar-se. Dirigindo-se ao conde de Selir, demandava: "com a maior urgência, rogo a Vossa Excelência queira avisar, pelo telégrafo, sobre o que consta a respeito de boatos de revolução [em] Portugal.” (14, fl. 17).

Entrementes, o ministro dos Negócios Estrangeiros orientava a chefia da Legação: "República proclamada. Governo Provisório presidido [pelo] doutor Teófilo Braga. Peço [que] comunique feliz nova [a] esse governo e [aos] nossos compatriotas. Ordem absoluta." (14, fl. 17)

No dia 7, referindo-se ao 5 de Outubro e isentando-se de "fazer alusões àquela desgraça irreparável", o cônsul na cidade de Santos declarava-se solidário com o demissionário Selir e invocando seu estatuto de "leal servidor da causa monárquica", solicitava exoneração do cargo, no que foi secundado pelo vice-cônsul (13). Em simultâneo, insistia a autoridade consular na capital baiana em pedir "notícias positivas [e] oficiais sobre os graves acontecimentos nos últimos dias ocorridos em Lisboa" (13) e em advertir, no dia seguinte: "receio desacato [ao] das armas reais [estampadas no] Consulado. Peço instruções sobre o assunto", além de informar que reivindicara às autoridades locais proteção para as instalações do imóvel diplomático (14, fl. 17v), no que foi prontamente atendido (13).

Em 9 de outubro, era a vez dos cônsules em Pernambuco e no Rio Grande do Sul. O primeiro, ao declarar que portugueses residentes naquele estado, por seu intermédio, rogavam informações sobre o "estado político da nossa pátria"; o segundo, consignando seu telegrama como "confidencialíssimo", expunha e requeria: "receio agitação política entre [a] colônia. Rogo a Vossa Excelência encarecidamente informar se é verdade Vossa Excelência e [o barão do] Rio Branco terem recebido comunicação oficial [sobre] mudança do regime em Portugal.” (14, fl. 18)

O cônsul em Manaus, a 12 de outubro, assim se expressou sobre o desenrolar da instauração do novo quadro político: "tenho, pois, a registrar prejuízos materiais e de vida [sofridos pela colônia portuguesa local], cuja reclamação estou preparando, com o auxílio de distinto advogado desta capital, para ulterior procedimento. E maior seria a calamidade se, por iniciativa deste Consulado, uma comissão de representantes da Associação Comercial e do corpo consular não interviesse no sentido de pacificar, de pronto, o movimento que ameaçava tomar extraordinárias proporções.” (13)

Às vésperas do retorno a Lisboa, evocando a preservação de sua autoridade, o conde de Selir escrevia àqueles cônsules determinando que, por ordem superior, o escudo e a bandeira do antigo regime deveriam ser imediatamente removidos da fachada dos imóveis diplomáticos (14, fl. 20v e 15, fl. 20v). Em 30 de outubro, estando a Legação do Rio Janeiro já sob a tutela do visconde de Salgado, o ministro 
Bernardino Machado interrogava-lhe "se todos os consulados hastearam como deviam [a] bandeira republicana." (19; 11, Cap. I) ${ }^{2}$

O que se observou, no entanto, foram desavenças incontornáveis, como se explicita no telegrama, ainda do dia 30, do senhor Correia de Almeida, presidente do Centro Republicano Português paraense, para o encarregado de negócios na Legação de Portugal no Rio de Janeiro: “Consulado aqui [em Belém do Pará] conserva escudo e continua [a] hastear [a] bandeira [da] monarquia [na] fachada [do] edifício, dando como pretexto não receber comunicações oficiais vossas. Indignação crescente. Pedimos vossa intervenção imediata, a fim [de] evitar conflitos eminentes entre portugueses.” (15, fls. 20-20v). A réplica não tardou. Sem dilação, o cônsul local, o visconde de Monte Redondo, telegrafou ao cônsul geral no Rio de Janeiro. In verbis: "Não recebi até hoje comunicação oficial [sobre] mudança [na] forma [de] governo. Não podendo continuar funções consulares aqui, resolvi demitir-me passando exercício ao respectivo chanceler." (14, fl. $21 \mathrm{v})$

\section{O RECONHECIMENTO EM PROCESSO}

Por telegrama remetido na noite do dia 5, o barão do Rio Branco autorizou Costa Mota a manter relações com o governo provisório, cientificando-lhe que o reconhecimento formal seria feito tão logo houvesse certeza de que a nova forma de governo tinha o respaldo da população e que era aceita "em toda ou quase toda a extensão do país” (6).

Na semana seguinte, por intermédio de mensagem cifrada ao titular da Legação em Lisboa, o ministro brasileiro expôs seu pensamento à luz de fatos e de análise mais ampla e consistente da situação. De imediato, ratificava o compromisso com o mais breve reconhecimento da República Portuguesa, ponderando, no entanto, sobre a necessidade de preservarem-se os interesses do Brasil. Em suas palavras:

[...] nós não precipitemos pondo-nos mal com vários governos europeus de que temos dependência de assunto de emigração para o Brasil e outros. As outras repúblicas estão procedendo com bastante cautela e algumas que consultamos, como a Argentina, o México e o Chile, não querem dar passo que lhes aliene boa vontade de certos governos europeus.

Justificava seu cuidado tendo em conta situação análoga na história de seu país, cuja república tinha sido

[...] reconhecida por Argentina e Uruguai dias depois de proclamada; mas tratava-se de uma questão americana e não de um acontecimento europeu como este. (...). Desejamos que o Brasil seja o primeiro, mas estou procurando que Estados Unidos e Argentina não venham se não muito depois. Potências europeias hão de achar ousado que nos adiantemos. Quanto [à] república francesa, sabe-se que ela se esforça

\footnotetext{
2 Embora o pavilhão verde escuro e escarlate, desde então, passasse a ser utilizado e vulgarizado, as cores, o escudo das armas, a esfera armilar e o detalhamento da bandeira nacional só ficariam oficialmente fixados em 30 de junho de 1911, conforme decreto da Assembleia Nacional Constituinte, publicado, no Diário do Governo, aprovando parecer de comissão especial por dela designada em 15 de outubro de 1910.
} 
a viver bem com as monarquias e não quer que a tomem como propagandista da República em terra alheia.

Ao final, uma vez mais pautando-se por habitual postura diplomática, orientava seu colaborador:

Convém aconselhar o governo provisório a reprimir excessos e mostrar que Portugal será uma república conservadora. Acrescentarei que tendo tido [a] república brasileira tão boas relações com os dois últimos reis, não lhe fica bem rompimento brusco com tão recente passado. Em jornais ingleses [e] franceses já apareceram intrigas e invenções dizendo que [a] revolução foi promovida e auxiliada pelo Brasil. Temos querido apenas formalidades usuais e deixar passar alguns dias para fazer as coisas com decoro" (6).

Em 15 de outubro, o ministro brasileiro avança em suas lucubrações, ao instruir seu mandatário em Lisboa para sondar o dirigente da diplomacia portuguesa sobre a hipótese de publicar, na semana seguinte, o decreto de convocação da Assembleia Constituinte, fixando a data de sua instalação, argumentando que tal providência era de grande importância não apenas para o posicionamento do Brasil como para o de "outro governo amigo", ou seja, o dos Estados Unidos da América, pelo que facilmente se infere na consulta a documentos a este correlatos (6).

Sem que a resposta lhe tivesse sido oferecida, a 16 Rio Branco confirmou seu propósito quanto à prioridade brasileira no reconhecimento da República Portuguesa. Novamente dizia: "precisamos proceder de modo a que outros governos da Europa e americanos não [nos] acusem de precipitação e parcialidade ou de desrespeito ao governo com que, ainda há dias, mantínhamos relações de amizade" (6).

De pronto, Costa Mota executou a incumbência comunicando a Rio Branco que o governo provisório se mostrava sensível à ponderação brasileira, mas que era imprescindível o restabelecimento de legislação eleitoral respeitante e a organização "de pessoal de confiança no interior do país", projetando-se que a sugestão tornar-se-ia realidade em fevereiro ou março próximos. Satisfeito, sem abdicar da prudência, o Barão corroborou e replicou: "sob condição [de] maior segredo, diga ao ministro dos Negócios Estrangeiros que isso facilitaria [a] diligência que estamos fazendo para que [os] Estados Unidos logo depois do Brasil, talvez no dia seguinte, reconheçam [o] novo regime.” E, peremptório, encerrava: "sobre isso é indispensável nada transpirar." (6)

Em simultâneo a essas gestões e com o desígnio de com elas obter pleno sucesso nas articulações, a 21 de outubro, reafirmando a necessidade da absoluta discrição nos contatos, o chanceler brasileiro solicitou ao seu imediato em Lisboa que "procurasse conhecer as instruções" que seus colegas, principalmente os ministros inglês e francês em Lisboa, tinham a respeito da legitimação internacional da nova república (6).

No mesmo dia, por telegrama confidencial e cifrado, Costa Mota respondeu-lhe, ao arrazoar que o ministro inglês, ausente da capital portuguesa,

[...] mandou seu secretário mostrar-me uma nota do Foreign Office, da qual extrai o seguinte: a fim [de se] evitar inconvenientes, governo inglês julga necessário decidirse sobre [qual] atitude adotar com relação [ao] governo provisório [de] Portugal. De 
acordo [com] procedimento seguido [em] idênticas circunstâncias, especialmente com Brasil, governo inglês propôs instruir seu representante [em] Lisboa para que trate com governo provisório como se fosse governo de fato de meu país com [o] qual está e desejando continuar com boas relações diferindo o pleno reconhecimento da República e do presidente para quando o país se pronunciar constitucionalmente, ficando entendido que $[\mathrm{o}]$ governo provisório procederá, em devido tempo, a essa manifestação da opinião pública. Logo depois, [o] governo inglês reconheceria plena e oficialmente (o) governo que fosse eleito e estabelecido constitucionalmente. Governo inglês mandando fazer pelo seu embaixador [nos] Estados Unidos [a] citada comunicação às grandes potências recomendando-lhes perguntar se respectivos governos estavam decididos a adotar este procedimento ou quais [eram] suas intenções. Governo inglês diz [que] seria para desejar que atitude [das] grandes potências [da] Europa fosse uniforme. França e Espanha já adotaram (5).

Afinal, o reconhecimento se concretizou. O desfecho das démarches de Rio Branco cumpriu-se ainda na noite de 21 de outubro, quando comunicou a José Pereira da Costa Mota que o presidente da república brasileira assinara carta de nomeação acreditando-o como enviado extraordinário e ministro plenipotenciário do Brasil perante o governo da República Portuguesa e ao determinar que encaminhasse nota a respeito ao ministro dos Negócios Estrangeiros. Em outro telegrama, emitido a seguir, apresentava-lhe minuta do texto do documento (6).

Pari passu, a Legação de Portugal no Rio de Janeiro foi destinatária de idêntica mensagem, logo retransmitida às autoridades em Lisboa. No texto cifrado, o conde de Selir mencionava que a assinatura da nova credencial importava no reconhecimento oficial do novo regime político português, pelo que já agendara a cerimônia de sua despedida formal junto ao gabinete do presidente Nilo Peçanha (18).

Às 19 horas do dia 22, Costa Mota informava que acabara de entregar a nota ao ministro Bernardino Machado “que, muito comovido e apertando a mão”, pediu-lhe que externasse ao presidente e ao chanceler brasileiros os seus agradecimentos (5). ${ }^{3}$

De toda maneira, em obediência ao protocolo, no dia seguinte, o ministro português enviou telegrama para a Legação no Rio de Janeiro: "signifique [ao] governo brasileiro toda nossa profunda gratidão pelo pronto reconhecimento [da] República Portuguesa. Hoje, [houve] entusiástica manifestação popular [de] afeto perante a Legação do Brasil” (14, fl. 12; 21).

Resguardada a primazia no reconhecimento, tal como anunciara Rio Branco dedicou-se a obter igual manifestação de outros países. Assim é que, em 23 de outubro, em feitio de urgência, telegrafou a Costa Mota:

Comunique já confidencialmente ao ministro dos Negócios Estrangeiros que, por proposta [que] mandei fazer, [o] governo argentino telegrafou ontem [ao] seu representante em Lisboa [para] anunciar [que fora] assinada nova credencial. Dos

\footnotetext{
3 Bernardino Luís Machado Guimarães era natural do Rio de Janeiro e ali viveu seus primeiros anos. Não é tido como um republicano histórico. Apesar disso, no início do século, incorporou-se ao Diretório do Partido Republicano. Apenas em fins de agosto de 1910 é que adquiriu posição de relevo, ao figurar entre os 10 deputados eleitos pelo círculo de Lisboa do Partido. Bernardino não participou da conspiração e da movimentação político-militar do 4 e 5 de outubro, preservando-se, por decorrência, do clima derrotista que tomou conta de grande parte dos revolucionários naquele momento decisivo. Sua presença no governo provisório foi motivo de surpresa de todos. Obra das maquinações de Afonso Costa que, a par de inegável "liderança" fora marginalizado do processo revolucionário até 3 de outubro.
} 
Estados Unidos, a resposta recebida ontem pela embaixada americana foi que tinham anunciado [ao] seu representante em Lisboa novas instruções para quando [for] restabelecida ordem constitucional. Ontem telegrafei [à] nossa embaixada [em Washington para] ver se obtemos reconhecimento provisório e nesse sentido embaixador americano telegrafou, mas creio que, sem convocação [da] constituinte, nada poderemos obter. P.S. - Informe-me logo que argentino cumprir instruções. (6).

A 24, Rio Branco, mostrando-se "ansioso" por desejar saber se o diplomata argentino satisfizera a citada ordem, informava que estava de posse de resposta do governo americano na qual ficava expresso que a aceitação do novo regime político por aquele país estaria condicionada ao seu convencimento de que a mudança institucional portuguesa contava com o apoio da sua população (6). Com efeito, a chancela em pauta só viria a ocorrer em 11 de junho de 1911(17) .4

Preventivamente e para evitar dissabores, em 18 de outubro, pelo ofício-circular $n^{\circ} 67$, oriundo da Direção Geral dos Negócios Políticos e Diplomáticos, o ministro Bernardino Machado se dirigia ao legatário de Portugal no Rio de Janeiro:

Para que Vossa Excelência o faça constar pelos meios convenientes, dando inclusivamente conhecimento à imprensa, se ainda aí não foi noticiado, comunico a Vossa Excelência que o Governo Provisório da República Portuguesa dará execução formal a todos os compromissos legais tomados pelo antigo regime. Rogo a Vossa Excelência se sirva inteirar-me da maneira como der cumprimento a esta determinação (12, maço 5).

A resposta veio a 9 de novembro: “[...] cumpre-me participar a Vossa Excelência que, tendo todos os jornais desta capital [Rio de Janeiro] publicado há tempo em telegrama de Lisboa essa matéria e tendo o Agente Financial mandado publicar agora a mesma notícia, julguei-a suficientemente conhecida para eu fazer nova publicação" (12, maço 5).

\section{A ESCOLHA DOS LEGATÁRIOS}

Na madrugada de 6 de outubro, ao obter notícias de Lisboa, o conde de Selir escreveu para o seu novo superior hierárquico, ministro Bernardino Machado: "Recebi telegrama. Caso seja certa [a] implantação [da] república [em] Portugal e não podendo, por [ser] convictamente monárquico, servir lealmente esse regime, considero-me demissionário." (14)

A resposta chegou-lhe no dia 8, na qual Machado declarava ter acatado a resolução que lhe fora encaminhada, condicionando-a à entrega do arquivo da Legação ao cônsul geral no Rio de Janeiro, o visconde de Salgado, que ficaria responsável pelo expediente da entidade (16).

\footnotetext{
${ }^{4}$ A República Portuguesa foi reconhecida pela Argentina também em 22 de outubro de 1910; pela Nicarágua, em 28 de outubro; pelo Uruguai, em 30 de outubro; pela Guatemala, em 16 de novembro; pela Costa Rica, em 29 de novembro; pelo Peru, em 5 de dezembro e pelo Chile, em 19 de dezembro. Em junho de 1911, além dos Estados Unidos da América, a República Francesa. Outras nações europeias, inclusive a vizinha Espanha, pautando-se pela exigência vinculante da Inglaterra, só o fizeram no e após o 11 de setembro de 1911, momento da promulgação da constituição republicana e da eleição do primeiro presidente. O temor de Rio Branco em perder a prioridade do reconhecimento para os argentinos explica-se, em grande parte, pelas articulações que o representante daquele país então desenvolveu em Lisboa, impulsionado, sem dúvida, pelo fato de ter sido Portugal o primeiro país a reconhecer a independência da Argentina.
} 
Nesse meio tempo, o barão do Rio Branco voltava a observar ao representante brasileiro em Lisboa que fizesse chegar à presidência do governo provisório e ao ministro dos Negócios Estrangeiros a conveniência em não haver demora na nomeação do sucessor de Selir (6).

No dia 10, em outro telegrama, o chanceler brasileiro era categórico no seu intento, ao advertir Costa Mota que o novo ministro português no Brasil deveria ser "homem moderado e jeitoso, para produzir boa impressão sobretudo na colônia portuguesa." E, bem direto, apontava que a indicação de Sebastião de Magalhães Lima seria excelente, a despeito de, em dada altura, dever retornar a Paris. Afirmava, ainda, que fora informado sobre possível nomeação de Jaime Séguier, concluindo que "esse também seria bom." $(3,5 \text { e } 6)^{5}$

No dia seguinte, porém, Rio Branco enviava um reparo àquelas suas manifestações: "Fui informado que o Grêmio Republicano Português [...] não deseja Séguier. Mencionei este nome somente porque apareceu entre os indicados em telegramas de Lisboa." (3 e 7)

Em 14 de outubro, enquanto Costa Mota mantinha tratativas relativamente à opção por Magalhães Lima, buscando igualmente evitar que o designado fosse João Chagas (5), o barão ministro insistia com seu emissário na capital portuguesa naquela escolha, pois "todos desejam que [ele] venha, mesmo que por pouco tempo", evocando que "o posto é importante para Portugal principalmente por ser numerosa a colônia" e reiterando que Costa Mota conversasse confidencialmente com Bernardino Machado no sentido de que, caso a preferência do governo recaísse sobre João Chagas, este assumisse a Legação do Rio de Janeiro “depois da missão preparatória e conciliatória de Magalhães Lima.” (3 e 7) ${ }^{6}$

Ato contínuo, Mota respondeu: “conferenciei com [o] ministro dos [Negócios] Estrangeiros sobre [a] nomeação [de] Magalhães Lima. [O ministro] prometeu-me fazer todos esforços para que ele, que está atualmente em Paris, aceite [o] posto de ministro plenipotenciário aí. Se não aceitar, não será [João] Chagas o nomeado, mas sim outra pessoa. Ministros francês, italiano e mexicano vieram ver-me anteontem [e] estão, como os restantes, em comunicação com os seus governos e disseram-me que, se continuasse $(\mathrm{m})$ o sossego e a paz que se nota em todo o país, o reconhecimento [da República Portuguesa] seria questão de pouco tempo. Espera-se que a Inglaterra, como aliada, dê o exemplo.” (2, 3 e 6$)$

Poucos dias depois, a 25 de outubro, o barão do Rio Branco despediu-se do conde de Selir, manifestando-lhe seu pesar pela "nobre resolução" e expressando o desejo de que a amizade e a correspondência pessoais entre eles permanecessem (10). Em retribuição, Selir informava seu regresso a Lisboa no dia 27 e que estava "deixando, por indicação do ministro dos Negócios Estrangeiros do Governo Provisório, o arquivo e o expediente da Legação ao cargo do cônsul geral de Portugal no Rio de Janeiro até a chegada do meu sucessor.” Aos agradecimentos, acrescentava a expressão das “indeléveis

\footnotetext{
${ }^{5}$ Sebastião de Magalhães Lima foi uma das mais proeminentes figuras do republicanismo português, publicista com projeção e trânsito internacionais e, durante décadas, líder da maçonaria lusitana. Escritor e diplomata, Jaime Séguier era, na ocasião, cônsul de Portugal em Paris.

${ }^{6}$ João Pinheiro Chagas foi jornalista e escritor e, desde sempre, ativista republicano. Com o 5 de Outubro, foi designado para a Legação de Portugal em Paris. Em 1911, chefiou o primeiro governo constitucional português.
} 
recordações das afetuosas relações que tive a honra de entreter com tão eminente e provecto estadista, e, que embora cessem as nossas relações oficiais, espero que as particulares continuarão no mesmo pé de cordial amizade com que sempre me honrou." $(8)^{7}$

Simultaneamente ao embarque do diplomata, as autoridades portuguesas telegrafaram ao visconde de Salgado determinando-lhe que oficiasse imediata e formalmente ao governo brasileiro que ele estava investido na condição de encarregado dos negócios na Legação do Rio de Janeiro (8, 22 e 23). Por intermédio de comunicação entregue no dia 29, Rio Branco acusou o recebimento da formalidade e exprimiu sua "satisfação em poder entrar em correspondência oficial com tão distinto funcionário português.” (13)

Por seu turno, em 16 de novembro, José Pereira da Costa Mota cientificava o Ministério das Relações Exteriores que, no dia anterior, entregara suas credenciais em Belém e que, nos trajetos de sua ida e volta, o Brasil fora saudado efusivamente pela população lisboeta, assim como se tinham realizado representações nos teatros e espetáculos de gala em homenagem ao Brasil, com "muitos vivas e saudações.” (5)

$\mathrm{Na}$ realidade, era significativo o momento do ato diplomático, posto que este aconteceu no aniversário da proclamação da república brasileira. Desse modo, àquelas manifestações populares acrescentou-se a que foi protocolarmente prestada pelo governo provisório, configurada no envio, ao Rio de Janeiro, do cruzador São Rafael, a fim de que representasse oficialmente Portugal nas comemorações do 15 de Novembro e na solenidade de posse do marechal Hermes da Fonseca na presidência do país. O texto do telegrama da Legação em Lisboa que transmitiu essa deliberação ao Ministério das Relações Exteriores afirmou ainda que o navio partiria de Lisboa no dia 26 (2), o que somente aconteceu passada quase uma semana (6). O retardamento certamente se explica pela frustrada possibilidade de o posto diplomático ser imputado a Sebastião de Magalhães Lima, que, deslocando-se de Paris para Lisboa, não alcançou a premente largada da embarcação (5).

Desse modo, em 4 de novembro, o ministro Bernardino Machado ordenou ao encarregado de negócios da Legação no Rio de Janeiro que comunicasse ao governo brasileiro estar o comandante do Adamastor, capitão-tenente João Manuel de Carvalho, qualificado como "enviado extraordinário em missão especial" da República Portuguesa naqueles dois atos solenes (8 e 10).

No mesmo dia, em contrapartida, o visconde de Salgado expôs a Bernardino que a comissão brasileira encarregada dos referidos festejos solicitava informação sobre a data de chegada do Adamastor ao Rio de Janeiro. Também, e muito importante, que a fizesse saber "como era a bandeira portuguesa" (18). A credenciada embarcação aportou na capital brasileira no dia 14 e o barão do Rio Branco, de imediato, recebeu seu mandatado comandante (15, fl. 23).

\footnotetext{
${ }^{7}$ João Carlos da Horta Machado da Franca, $1^{\circ}$ conde de Selir, já estivera no Rio de Janeiro, onde serviu na Legação portuguesa como secretário. Nessa nova função, ali chegou em junho de 1908, transferido da chefia da representação diplomática de Portugal em Haia, para onde foi designado o conselheiro Camelo Lampreia, seu antecessor na capital brasileira. Selir morreu em Lisboa menos de dois meses após sua volta definitiva do Brasil.
} 
Somente em 23 de novembro a escolha do ocupante da Legação portuguesa no Rio de Janeiro ficou assentada. E a escolha não contemplou as personalidades cogitadas. Como se lê em telegrama cifrado de Costa Mota para o Ministério das Relações Exteriores, na oportunidade o governo provisório sondou o seu par brasileiro sobre a designação do ministro do Fomento, Antônio Luís Gomes, para seu mandatário diplomático no Brasil. Sem hesitar, o barão do Rio Branco respondeu: "será aceito com muito prazer." (2 e 5)

A destacar que, naqueles dias, a correspondência diplomática conferiu relevo a fato marcante da história brasileira. Aconteceu que, em 21 de novembro, por meio de telegrama cifrado, o cônsul Salgado informou ao Ministério dos Negócios Estrangeiros a eclosão de motim na armada brasileira, dizendo que a "marinhagem (sic) alega mau tratamento, falta de meios [e] comida. Espera-se acordo com o governo brasileiro" (18). A 23, o teor de nova mensagem alterava o tom e a qualidade da informação: “esquadra brasileira revoltada ameaça bombardear Rio de Janeiro.” (18)

Por derradeiro, no 26 de novembro, duas outras comunicações telegráficas foram expedidas para Lisboa. Uma, identificava e caracterizava o marinheiro João Cândido como "o chefe da revolta", dita "da Chibata". Ao mesmo tempo, avaliava estar o "Consulado exposto [a] balas [e] empregados fugidos" e apontando o alarmismo vigorante na imprensa periódica. A segunda, noticiava que o Congresso concedera anistia aos revoltosos, sujeita à entrega dos navios de guerra ao governo brasileiro (18).

No final do mês, a Legação brasileira em Lisboa foi cientificada da escolha do representante diplomático português no Brasil (4). Para completar, a 23 de dezembro, o presidente Teófilo Braga, dirigindo-se ao seu homólogo Hermes da Fonseca, sempre evocado como "grande e bom amigo", cumpria o preceito de apresentar-lhe Antônio Luís Gomes como enviado extraordinário e ministro plenipotenciário da República Portuguesa junto ao governo brasileiro (9). ${ }^{8}$

Constata-se, pois, que o exercício das funções ministeriais por Gomes, sem embargo de ter-se iniciado com o advento do novo regime, não completou dois meses. A 22 de novembro, ele demitiu-se, muito possivelmente premido pelas disputas e antagonismos intrapartidários. Nas suas Memórias, Tomás da Fonseca, que também integrava o governo provisório, testemunhou: “o pobre António Luís Gomes, farto de ser incomodado pelos comitês de carbonários a exigirem-lhe demissões de funcionários, deixava o Ministério do Fomento" (apud RAMOS, 2001, p. 385).

De todo modo, a indicação de Gomes inaugurou procedimento exercitado, por largos anos, por parte do governo português: o da nomeação de responsáveis pelo comando de legações e, logo em seguida, pelo cargo de embaixador, como decisão diretamente relacionada e condicionada pela política interna lusitana, inclusive pelas citadas divergências no interior do Partido Republicano Português.

\footnotetext{
${ }^{8}$ Gomes era natural de Oliveira de Azeméis, mas foi um portuense por excelência. Um típico nortenho, o que importava bem dado que a emigração para o Brasil era maciçamente oriunda daquela região. Tornou-se bacharel e doutor em Direito pela Universidade de Coimbra, onde também lecionou, e, mais tarde, foi reitor.
} 
Nesse sentido, cabe aludir que, em paralelo à designação de Gomes para a Legação no Rio de Janeiro, houve a indicação de figuras proeminentes para o exercício de comando de missões diplomáticas de $1^{\text {a }}$. Classe, como Guerra Junqueiro, na Legação em Berna; Manuel Teixeira Gomes, na de Londres; João Chagas, em Paris e, na de Madri, em outubro de 1911, José Relvas, que, desde o 5 de Outubro ocupava o ministério das Finanças do governo provisório, expressivo testemunho da relevância da agenda das relações internacionais no reconhecimento e na consolidação do novo regime.

\section{GOMES NO RIO}

Em 23 de janeiro de 1911, por ofício reservado, Costa Mota comunicou ao ministro Rio Branco que, no dia seguinte, Antônio Luís Gomes partiria de Lisboa para assumir suas atribuições no Rio de Janeiro. Reportando-se ao noticiário da imprensa lisboeta, informava que "os jornais monárquicos muito criticaram a sua escolha, dizendo que o governo provisório nomeara representante de Portugal no Brasil um negociante de curtume estabelecido no Rio de Janeiro" (3).

Gomes fez-se acompanhar de dois auxiliares diretos, com os quais guardava afinidades: o novo cônsul geral no Rio de Janeiro, Dr. Francisco José Fernandes Costa, “um dos mais ardentes e devotados propagandistas do Partido Republicano Português" e o jovem bacharel em direito Domingos Lopes Fidalgo, nomeado adido de Legação (5). Após ter feito escalas nas cidades de Recife e de Salvador, em 6 de fevereiro o vapor Aragon ancorou na baia da Guanabara (12).

Antônio Luís Gomes não era um adventício nas terras brasileiras. Outrora, no Rio de Janeiro, tinha sido fundador e sócio número 1 do Grêmio Republicano Português local. Tempos nos quais, relembre-se, acumulou fortuna no Rio Grande do Sul. De volta ao Porto no início do século, filiou-se ao Partido Republicano Português.

Gomes não poupou elogios à calorosa recepção promovida por diversificados segmentos, quer de portugueses, quer de brasileiros, oficiais ou não.

Cumprindo percurso contrário, o visconde de Salgado, viajou do Rio para Lisboa em 23 de fevereiro. Desde 14 de janeiro fora transferido para o recém-criado consulado português em Casablanca. Posteriormente, foi nomeado para postos diplomáticos em Cádis e em Marselha. Não os assumiu, todavia, em virtude de repetidos pedidos de licença, aposentando-se extraordinariamente em maio de 1912 (11, p. 161).

Em 25 de fevereiro, na solenidade de entrega de suas credenciais ao presidente da república brasileira, em curto discurso, Antônio José Gomes renovou os seus agradecimentos e os de seu governo pelo "pronto reconhecimento" da República portuguesa por parte do Brasil e a primazia em proclamálo (9 e 12), gratidão que ele estendia "a este grandioso país [ao qual] me prendem laços de sangue (...) e sentimentos da mais elevada ordem moral" (9 e 10).

Palavras de circunstâncias ou não, certo é que, naquela conjuntura e com tais protagonistas, o evento e a alocução marcavam o início de nova era nas relações diplomáticas luso-brasileiras. 


\section{FONTES}

(1) BRASIL. Ministério das Relações Exteriores. Arquivo Histórico do Itamaraty. Missões diplomáticas brasileiras - Embaixadas. Ofícios (1909).

(2) BRASIL. Ministério das Relações Exteriores. Arquivo Histórico do Itamaraty. Missões diplomáticas brasileiras - Embaixadas. Ofícios (1910).

(3) BRASIL. Ministério das Relações Exteriores. Arquivo Histórico do Itamaraty. Missões diplomáticas brasileiras - Embaixadas. Ofícios (1911).

(4) BRASIL. Ministério das Relações Exteriores. Arquivo Histórico do Itamaraty. Missões diplomáticas brasileiras - Embaixadas. Lisboa. Despachos (1908-1911).

(5) BRASIL. Ministério das Relações Exteriores. Arquivo Histórico do Itamaraty. Missões diplomáticas brasileiras - Embaixadas. Legação em Lisboa. Telegramas recebidos (1900-1910).

(6) BRASIL. Ministério das Relações Exteriores. Arquivo Histórico do Itamaraty. Missões diplomáticas brasileiras - Embaixadas. Lisboa. Telegramas expedidos (1900-1912).

(7) BRASIL. Ministério das Relações Exteriores. Arquivo Histórico do Itamaraty. Repartições consulares brasileiras - Lisboa. Ofícios (1911).

(8) BRASIL. Ministério das Relações Exteriores. Arquivo Histórico do Itamaraty. Representações diplomáticas estrangeiras no Brasil - Correspondência. Portugal. Notas recebidas, telegramas recebidos, notas e telegramas (1908-1910).

(9) BRASIL. Ministério das Relações Exteriores. Arquivo Histórico do Itamaraty. Representações diplomáticas estrangeiras no Brasil - Correspondência. Portugal. Notas recebidas, telegramas recebidos, notas e telegramas (1911-1913).

(10) BRASIL. Ministério das Relações Exteriores. Arquivo Histórico do Itamaraty. Representações diplomáticas estrangeiras no Brasil - Correspondência. Portugal. Telegramas expedidos, notas e telegramas expedidos (1908-1911).

(11) PORTUGAL. Ministério dos Negócios Estrangeiros. Annuario diplomático e consular português. 19101913. Lisboa: Imprensa Nacional, 1913.

(12) PORTUGAL. Ministério dos Negócios Estrangeiros. Arquivo Histórico Diplomático. Legação de Portugal no Rio de Janeiro. Correspondência recebida. 1909-1911. Caixa 230, série A.

(13) PORTUGAL. Ministério dos Negócios Estrangeiros. Arquivo Histórico Diplomático. Legação de Portugal no Rio de Janeiro. Correspondência recebida e expedida. Ano: 1910. Maço 49.

(14) PORTUGAL. Ministério dos Negócios Estrangeiros. Arquivo Histórico Diplomático. Livro de registro de telegramas recebidos e expedidos pela Legação de Sua Majestade Fidelíssima no Brasil. [Termo de abertura: "Petrópolis, 31 de janeiro de 1910. Ass. José Lampreia, adido da Legação].

(15) PORTUGAL. Ministério dos Negócios Estrangeiros. Arquivo Histórico Diplomático. Livro de registro de telegramas recebidos e expedidos pela Legação de Sua Majestade Fidelíssima no Brasil. [Termo de abertura: "Petrópolis, 31 de janeiro de 1910. Ass. José Lampreia, adido da Legação]. 1910-1911. Livro 108.

(16) PORTUGAL. Ministério dos Negócios Estrangeiros. Arquivo Histórico Diplomático. Núcleo Antigo - Copiador. Telegramas. Repartição do Gabinete. Livro 534-B. 
(17) PORTUGAL. Ministério dos Negócios Estrangeiros. Arquivo Histórico Diplomático. Reconhecimento da República Portuguesa pelas potências. Pasta: Brasil.

(18) PORTUGAL. Ministério dos Negócios Estrangeiros. Arquivo Histórico Diplomático. Telegramas recebidos. Outubro/ novembro/ dezembro de 1910. [pelo] Dr. Bernardino Luiz Machado Guimarães. [Legação e Consulado no Rio de Janeiro].

(19) PORTUGAL. Ministério dos Negócios Estrangeiros. Arquivo Histórico Diplomático. Telegramas expedidos. Outubro / novembro / dezembro de 1910 [pelo] Dr. Bernardino Luiz Machado Guimarães - Rio de Janeiro (Legação e Consulado).

\section{REFERÊNCIA}

RAMOS, R. A segunda fundação (1890-1926). Lisboa: Estampa, 2001. (Col. História de Portugal, v. 6. Dirigida por José Mattoso). 